\title{
Erratum to: Marine Ecological Processes
}

\author{
Ivan Valiela
}

\section{Erratum to:}

I. Valiela, Marine Ecological Processes, DOI 10.1007/978-0-387-79070-1

In the original version of the book, the belated correction to include the list of alphabetical entries $\mathrm{N}$ and $\mathrm{O}$ in the reference list has to be incorporated in the backmatter of the book. The erratum book has been updated with the change.

The updated online version of this book can be found at http://dx.doi.org/10.1007/978-0-387-79070-1 